\title{
Three phase partitioning, a scalable method for the purification and recovery of cucumisin, a milk-clotting enzyme, from the juice of Cucumis melo var. reticulatus
}

\author{
Mohammed Gagaoua ${ }^{\mathrm{a}, \mathrm{b}, *, 1}$, Ferhat Ziane ${ }^{\mathrm{b}}$, Sabrina Nait Rabah ${ }^{\mathrm{b}}$, Nawel Boucherba ${ }^{\mathrm{c}}$, \\ Amel Ait Kaki El-Hadef El-Okki ${ }^{\mathrm{b}}$, Amel Bouanane-Darenfed ${ }^{\mathrm{d}}$, Kahina Hafid ${ }^{\mathrm{a}, \mathrm{b}}$ \\ a Equipe MaQuaV, INATAA, Université Frères Mentouri Constantine, Route de Ain El-Bey, 25000 Constantine, Algeria \\ b INATAA, Université Frères Mentouri Constantine, Route de Ain El-Bey, 25000 Constantine, Algeria \\ ${ }^{c}$ Laboratory of Applied Microbiology, Faculty of Nature Science and Life, University of Bejaia, Targa Ouzemmour, 06000 Bejaia, Algeria \\ ${ }^{\mathrm{d}}$ Laboratory of Cellular and Molecular Biology, Microbiology Team, University of Sciences and Technology of Houari Boumediene, PO Box 32, El Alia, Bab \\ Ezzouar, 16111 Algiers, Algeria
}

\section{A R T I C L E I N F O}

Article history:

Received 3 November 2016

Received in revised form 12 March 2017

Accepted 14 April 2017

Available online 17 April 2017

Keywords:

Milk-clotting enzyme

Cucumis melo

Cucumisin

Recovery

Purification

Three phase partitioning (TPP)

\begin{abstract}
A B S T R A C T
Cucumisin [EC 3.4.21.25] was first purified from Cucumis melo var. reticulatus juice by three-phase partitioning (TPP). Optimum purification parameters of the TPP system were determined as $60 \%$ ammonium sulfate saturation with 1.0:1.25 ratio of crude extract: $t$-butanol at $\mathrm{pH}$ and temperature of 8.0 and $20^{\circ} \mathrm{C}$, respectively. Cucumisin was purified with 4.61 purification fold and $156 \%$ activity recovery. The molecular weight of the recovered cucumisin was determined as $68.4 \mathrm{kDa}$ and its isoelectric point is 8.7. Optimum $\mathrm{pH}$ and temperature of cucumisin were $\mathrm{pH} 9.0$ and $60-70^{\circ} \mathrm{C}$, respectively. The protease was very stable at $20-70^{\circ} \mathrm{C}$ and a pH range of 2.0-12.0. $\mathrm{Km}$ and $V \max$ constants were $2.24 \pm 0.22 \mathrm{mgmL}^{-1}$ and $1048 \pm 25 \mu$ $\mathrm{Mmin}^{-1}$, respectively. The enzyme was stable against numerous metal ions and its activity was highly enhanced by $\mathrm{Ca}^{2+}, \mathrm{Mg}^{2+}$, and $\mathrm{Mn}^{+2}$. Cucumisin activity was 2.35 -folds increased in the presence of $5 \mathrm{mM}$ of $\mathrm{CaCl}_{2}$. It was inactivated by $\mathrm{Co}^{2+}, \mathrm{Cd}^{2+}, \mathrm{Zn}^{2+}$ and $\mathrm{Fe}^{2+}$ and dramatically by PMSF. Cucumisin milk-clotting activity was highly stable when stored under freezing $\left(-20^{\circ} \mathrm{C}\right)$ compared at $4{ }^{\circ} \mathrm{C}$ and $25^{\circ} \mathrm{C}$. Finally, TPP revealed to be a useful strategy to concentrate and purify cucumisin for its use as a milk-clotting enzyme for cheese-making.
\end{abstract}

(ㄷ) 2017 Elsevier B.V. All rights reserved.

\section{Introduction}

Milk-clotting enzymes (MCEs) are the primary active agents in cheese-making [1]. Several MCE preparations of animal, microbial, and plant origin have been discovered [2]. These enzymes are all proteases, one of the most important enzymes used in food industry, contributing to about $60 \%$ of the total world enzyme market [3]. Increasing world cheese production and consumption together with the scarcity on calf rennet have stimulated MCE research from alternative new sources, which has been directed towards plant proteases sources $[4,5]$. Among plant proteases, we found serine proteases. Once thought to be rare in plants, in recent years, they

\footnotetext{
* Corresponding author at: Equipe MaQuaV, INATAA, Université Frères Mentouri Constantine, Route de Ain El-Bey, 25000 Constantine, Algeria.

E-mail addresses: gmber2001@yahoo.fr, mgagaoua@inataa.org (M. Gagaoua).

1 Present adress: UMR1213 Herbivores, INRA, VetAgro Sup, Clermont université, Université de Lyon, 63122 Saint-Genès-Champanelle, France.
}

have been isolated and purified from different parts of several plant species, including latex, seeds, leaves, flowers, stems, and fruits [6]. They are grouped into six clans of which the two largest are the (chymo)trypsin-like and subtilisin-like clans [7]. The later is the second largest clan of the superfamily of subtilisins. Plant subtilisins are homologs of the bacterial subtilisins that fulfill highly specific functions in plant development and signaling cascades [8]. Over the last years, numerous plant subtilisins, also referred as cucumisinlike proteases, are reported [6] and used in food industry, namely in cheese-making [5,9-11].

Cucumisin (EC 3.4.21.25), an extracellular serine protease from Cucumis melo, is the well known characterized plant subtilisin $[12,13]$. This proteolytic enzyme was purified for the first time in 1975 by Kaneda and Tominaga from the sarcocarp, where it accumulates up to $10 \%$ of total soluble proteins of melon. Further cucumisin-like proteases have been purified from other cucurbitaceous plants and characterized for their broad substrate specificity and optimum temperature and $\mathrm{pH}$ [14-16]. The amino 
acid sequences around the reactive Ser and His of cucumisin have been also identified [17]. Yamagata and co-workers were the first to predict the primary structure of cucumisin from the cDNA [18].

Numerous studies have conducted many investigations on ways to isolate this proteolytic enzyme from the different parts of melon fruit or cucurbitaceous plants. The common methods for the purification of cucumisin are chromatographic techniques and often include ammonium sulfate precipitation, column chromatography, gel-filtration and affinity chromatography [13,19-23]. Three phase partitioning (TPP), an emerging non-chromatographic technique, may be considered a more attractive purification technology compared to the other processing methods since it offers major advantages in high throughput of desired product, easy to scale up and cost effective. Studies on the usage of TPP for proteases purification either as one-step purification methodology or being coupled with other techniques have been successfully reported [5,24]. This bioseparation technique is a three-stage batch method, which is a hybrid of salting out and alcohol precipitations for extracting, purifying and concentrating proteins for use in small or large manufacturing operations [25]. It consists of three phases and mainly utilizes high concentrations of well-buffered aqueous solutions along with equal volumes of alcohol. The two liquid layers will separate and a thin layer of precipitate filled with the desired products will form between these phases, creating a three-phase mixture.

Herein, we report for the first time the use of this simple, efficient and scalable TPP method for purification and fast recovery of cucumisin from the juice of $C$. melo var. reticulatus. The optimal parameters to achieve a maximum purity and yield of cucumisin using TPP system were also investigated. Overall characterization of the recovered enzyme was performed and its potential use as a milk-clotting enzyme was studied.

\section{Materials and methods}

\subsection{Preparation of cucumisin extracts}

During the summer of 2015, fully fresh mature melons (pieces of an average weight of $2.1 \mathrm{~kg}$ ) were obtained from plants, in the same locality in Kabylia region (a part of the Tell Atlas mountains located at the edge of the Mediterranean Sea), Algeria. They were identified by a botanist as Cucumis melo var. reticulatus. Melon fruits were cleaned and washed of any adhering residue. Then, each melon was divided into four parts: placenta, sarcocarp, seeds and juice as described by Nait Rabah and Ziane [26]. Thus, crude protein extracts from solid parts were obtained by using Ultra-Turrax T18 homogenizer at $20,000 \mathrm{rpm}(2 \times 20 \mathrm{~s}$ bursts $)$ (IKA Werke GmbH, Germany). By screening the milk-clotting activity of each part, the highest activity was found in the fruit juice. Thus, juice melon was used in this study as primary protein source for cucumisin extraction and purification by TPP system. Briefly, the fresh recovered juice was mixed (1:1) with sodium phosphate buffer (30 mM, pH 6.5). The obtained homogenate was then left to stand under a continuous stirring $(200 \mathrm{rpm})$ for $30 \mathrm{~min}$ at $4{ }^{\circ} \mathrm{C}$ before filtration through a double-layered cheesecloth. The clarified juice was centrifuged at $4000 \mathrm{rpm}$ at $4{ }^{\circ} \mathrm{C}$ for $10 \mathrm{~min}$ to collect the supernatant, which was subjected to ammonium sulfate $\left(\left(\mathrm{NH}_{4}\right)_{2} \mathrm{SO}_{4}\right)$ precipitation up to $75 \%$ saturation. The pellet obtained was dissolved in the same buffer and dialyzed overnight (MWCO: $14 \mathrm{kDa}$ ) against two changes of $5 \mathrm{~L}$ of $30 \mathrm{mM}$ sodium phosphate buffer, $\mathrm{pH} 6.5$ at $4{ }^{\circ} \mathrm{C}$. The crude clarified and dialyzed enzyme extract represented as "crude melon juice cucumisin extract" was subjected for further three phase partitioning studies.
Table 1

Effect of some usual salts and organic solvents on partitioning of cucumisin from fresh Cucumis melo var. reticulatus by three phase partitioning.

\begin{tabular}{lllc}
\hline Salt & $\begin{array}{l}\text { Relative enzyme } \\
\text { activity (\%) }\end{array}$ & $\begin{array}{l}\text { Organic } \\
\text { solvent }\end{array}$ & $\begin{array}{l}\text { Relative enzyme } \\
\text { activity (\%) }\end{array}$ \\
\hline Ammonium sulfate & $100 \pm 0.0$ & t-butanol & $100 \pm 0.0$ \\
Potassium sulfate & $67 \pm 1.8$ & n-propanol & $51 \pm 4.5$ \\
Sodium sulfate & $66 \pm 2.4$ & n-butanol & $49 \pm 3.2$ \\
Magnesium sulfate & $58 \pm 4.2$ & Iso propanol & $44 \pm 3.3$ \\
Sodium chloride & $37 \pm 3.6$ & Petroleum ether & $19 \pm 1.3$ \\
Potassium chloride & $34 \pm 2.7$ & Ethanol & $17 \pm 0.9$ \\
\hline
\end{tabular}

The values are means \pm standard deviation of three independent experiments.

\subsection{Three phase partitioning of cucumisin}

Prior the TPP process, different usual salts (ammonium sulfate, potassium sulfate, sodium sulfate, magnesium sulfate, sodium chloride and potassium chloride) and organic solvents (tertbutanol, $n$-butanol, $n$-propanol, Iso propanol, petroleum ether and ethanol) were assayed as described by Gagaoua et al. [27]. The results showed that tert-butanol and ammonium sulfate give the best results for the TPP process (Table 1). After that, TPP experiments were carried out using these two products as Gagaoua et al. [28]. Briefly, the crude melon juice cucumisin extract was saturated at room temperature with $30 \%\left(\mathrm{NH}_{4}\right)_{2} \mathrm{SO}_{4}$, followed by addition of an equal volume of tert-butanol. The mixture was gently vortexed and then allowed to stand for $1 \mathrm{~h}$ at room temperature. Afterwards, the mixture was centrifuged at $3000 \mathrm{rpm}$ for $5 \mathrm{~min}$ at $10^{\circ} \mathrm{C}$ to facilitate the separation of the phases. The upper $t$-butanol phase was removed by a Pasteur pipette. The lower aqueous phase and the interfacial phase were separated carefully and analyzed for enzyme activity and protein content. The interfacial precipitate was dissolved in $30 \mathrm{mM}$, pH 6.5 sodium phosphate buffer and dialyzed.

The effect of salt concentrations (30,40, 50, 60, 70 and 80\%) $(\mathrm{w} / \mathrm{v})$ on the crude enzyme extract for the TPP at the constant crude extract: $t$-butanol ratio (1.0:1.0) was investigated. After that, various t-butanol ratios (crude extract: $t$-butanol; 1.0:0.5, 1.0:0.75, $1.0: 1.0,1.0: 1.25,1.0: 1.5$, and 1.0:2.0) were used with a constant $\left(\mathrm{NH}_{4}\right)_{2} \mathrm{SO}_{4}$ saturation at $60 \%$ at room temperature. After the ammonium sulfate and t-butanol, effects with different $\mathrm{pH}$ values of medium study were tested. Crude extract was saturated with $60 \%$ $\left(\mathrm{NH}_{4}\right)_{2} \mathrm{SO}_{4}$ and $\mathrm{pH}$ was adjusted to $3,4,5,6,7,8,9$ and 10 , then 1.0:1.25 t-butanol was added and the best $\mathrm{pH}$ value on the partitioning behavior of cucumisin was investigated. Finally, the temperature of the system was varied from $5^{\circ} \mathrm{C}$ to $40^{\circ} \mathrm{C}$ to determine the best value leading to obtain the best partitioning behavior of the system using the optimized conditions of $\left(\mathrm{NH}_{4}\right)_{2} \mathrm{SO}_{4}(60 \%)$, t-butanol (1.0:1.25) and $\mathrm{pH}$ (8.0). After the optimization of the parameters $\left(\mathrm{pH},\left(\mathrm{NH}_{4}\right)_{2} \mathrm{SO}_{4}\right.$, tert-butanol and temperature) affecting the TPP process, three repetitions were conducted to confirm the results and calculate the overall recovery profile of cucumisin. The interfacial phase always containing the higher cucumisin activity was collected, dissolved in $30 \mathrm{mM}$, pH 6.5 sodium phosphate buffer and dialyzed overnight against the same buffer. The dialyzed enzyme was stored at $+4^{\circ} \mathrm{C}$ or $-20^{\circ} \mathrm{C}$ until use for further characterization studies in order to determine the general biochemical properties.

\subsection{Protein estimation}

Total protein concentration of protein extracts and purified samples were quantified by the dye binding method of Bradford [29] using the Bio-Rad Protein Assay (Bio-Rad Laboratories Inc.). Calibration curve for the estimation of protein concentration was generated using bovine serum albumin (BSA) as standard protein. 


\subsection{Enzymatic activity measurements}

The protease activity of the recovered cucumisin was determined according to the method described by Gagaoua et al. [4] with modifications. Briefly, the proteolytic reaction mixture consisted of the incubation of $100 \mu \mathrm{L}$ of enzyme solution with $0.5 \mathrm{~mL}$ of bovine casein $(5 \mathrm{mg} / \mathrm{mL}$ dissolved in $50 \mathrm{mM}$ Tris- $\mathrm{HCl}$ buffer, $\mathrm{pH}$ 8.0 ) at $37^{\circ} \mathrm{C}$ for $30 \mathrm{~min}$. The enzyme reaction was stopped by adding $0.5 \mathrm{~mL}$ of trichloroacetic acid (TCA) [10\% (w/v)]. The mixture was then kept for $30 \mathrm{~min}$ at $4{ }^{\circ} \mathrm{C}$. The supernatant was obtained by centrifugation at $4000 \mathrm{rpm}$ for $10 \mathrm{~min}$ and then filtered through $2 \mu \mathrm{m}$ filter device (Millipore, Billerica, MA, USA). The protease activity was determined with a spectrophotometer (UVIKON 923, BiotekInstruments, Winooski, VT, USA) by measuring the absorbance of TCA soluble peptides in the supernatant at $280 \mathrm{~nm}$. One unit (U) of protease activity was defined as the amount of enzyme that hydrolyzes casein to release $1 \mu \mathrm{g}$ tyrosine in $1 \mathrm{~min}$ under the aforementioned conditions, as the activity resulting from 0.01 absorbance unit at $280 \mathrm{~nm}$ per min. The results are expressed as a mean of three readings with an estimated error of $\pm 5 \%$.

\subsection{Milk-clotting activity}

Milk clotting activity (MCA) was determined according to the protocol of Arima et al. [30] as recently reported by Gagaoua et al. [28]. Briefly, the substrate was prepared by dissolving commercial bovine skimmed milk powder in $100 \mathrm{~mL}$ of $10 \mathrm{mM} \mathrm{CaCl}_{2}$ to a final concentration of $12 \%(\mathrm{w} / \mathrm{v}, \mathrm{pH} 6.4)$. The substrate $(1 \mathrm{~mL})$ was pre-incubated for $10 \mathrm{~min}$ at $37^{\circ} \mathrm{C}$ and $0.1 \mathrm{~mL}$ of the recovered cucumisin was added. Test tubes were periodically rotated by hand until appearance of visible discrete particles sing of coagulation. One milk-clotting unit was defined as the amount of enzyme that clots $10 \mathrm{~mL}$ of the substrate within $40 \mathrm{~min}(2400 \mathrm{~s})$ at $37^{\circ} \mathrm{C}$. The following formula was used:

$\mathbf{M C A}(\mathbf{U} / \mathbf{m l})=\frac{2400 * \mathbf{V}}{\mathbf{t}} * \mathbf{v}$

where " $\mathrm{V}$ " is the volume of milk $(\mathrm{mL})$, " $v$ " the volume of enzyme $(\mathrm{mL})$ and " $\mathrm{t}$ " the clotting time in seconds.

The effect of different concentrations of $\mathrm{CaCl}_{2}$ on $\mathrm{MCA}$ was determined using a milk solution with varying concentration of $\mathrm{CaCl}_{2}$ (0.0-60 mM). Additionally, MCA was tested by using different temperatures ranging from 35 to $80^{\circ} \mathrm{C}$ and $\mathrm{pH}$ ranges from 5.5-8.5. For stability, the prepared milk was mixed with the recovered enzyme and incubated at two temperatures $\left(37\right.$ and $50^{\circ} \mathrm{C}$ ) and after different times $(0,15,30,45,60,120$ and $180 \mathrm{~min})$ the tubes were tested for MCA. All the assays were performed by the addition of $0.1 \mathrm{~mL}$ of the recovered cucumisin to $1.0 \mathrm{~mL}$ of skimmed milk prepared following the standard conditions above. The values presented are the average of three independent experiments

\subsection{SDS-PAGE analysis and zymography}

Sodium dodecyl sulfate polyacrylamide gel electrophoresis (SDS-PAGE) was performed according to the Laemmli method using $10 \%$ separating and $4 \%$ stacking gels [31]. Ten micrograms of proteins were loaded and then subjected to separate at $4{ }^{\circ} \mathrm{C}$. After separation, the gel was stained overnight with staining solution (4.9 mM Coomassie Brilliant Blue G-250) in 50\% (v/v) ethanol and $7.5 \%(\mathrm{v} / \mathrm{v})$ acetic acid [28]. Protein patterns were then visualized after distaining the gel until a clear background was achieved. A mixture of protein with a known molecular weight standard (10-250 kDa, \#161-0374) obtained from Bio-Rad Laboratories, Hercules, CA, was used. The molecular weight of the protein bands was calculated using the Un-Scan-It gel 6.1 analysis program (Silk Scientific, Orem, UT).
Zymography analysis was performed on the purified cucumisin according to Garcia-Carreno et al. [32] using the above SDS-PAGE conditions. After electrophoresis, the proteins in the gel were renaturated by washing with $2.5 \%(\mathrm{v} / \mathrm{v})$ Triton X-100 for 30 min with shaking to remove SDS, and then washed twice with deionized water. The gel was then immersed in $50 \mathrm{~mL}$ of $2 \%$ pure casein in $50 \mathrm{mM}$ Tris- $\mathrm{HCl}$ buffer $(\mathrm{pH} 7.5)$ for $30 \mathrm{~min}$ at $4{ }^{\circ} \mathrm{C}$, and then incubated at $37^{\circ} \mathrm{C}$ for $2 \mathrm{~h}$ in order to allow the substrate to diffuse into the gel at reduced enzyme activity. Thereafter, the gel was washed with deionized water, and immediately stained and distained as previously described. A clear zone on the gel was considered as protease activity.

\subsection{Isoelectric point $(p \mathrm{I})$}

The isoelectric point $(\mathrm{pI})$ of the recovered cucumisin was determined by exploiting the property of protein precipitation when the $\mathrm{pH}$ of a mixture is adjusted. Herein, we used the method first described by Nath and Dutta [33] and recently reported by Gagaoua et al. [28] in a series of glycine- $\mathrm{HCl}$ buffer, acetate buffer, phosphate buffer and glycine-NaOH buffer prepared at intervals of 0.1 on the $\mathrm{pH}$ scale. The $\mathrm{pH}$ of the solution giving maximum turbidity after enzyme incubation for five minutes indicates the $\mathrm{p} I$ of the given enzyme fraction.

\subsection{Effect of temperature on the activity and stability of cucumisin}

The temperature profile of cucumisin was determined by performing the standard assay procedure using casein at different temperatures $\left(20,30,40,50,55,60,65,70,75,80\right.$, and $\left.90^{\circ} \mathrm{C}\right)$. The relative activities as percentages were expressed as the ratio of cucumisin activity obtained at a certain temperature to the maximum activity obtained at the given temperature range. The thermal stability was determined by measuring the residual activity at the same temperatures. After desired incubation periods ( $2 \mathrm{~h}$ with continuous shaking), enzyme aliquots were withdrawn and assayed at optimal assay conditions to determine the residual enzyme activity.

\subsection{Effect of $\mathrm{pH}$ on the activity and stability of cucumisin}

The optimal $\mathrm{pH}$ for the enzyme activity was determined in the range of 2.0-12.0 using $50 \mathrm{mM}$ citrate buffer ( $\mathrm{pH} 2.0-5.0$ ), $50 \mathrm{mM}$ sodium phosphate buffer ( $\mathrm{pH} 6.0-7.0$ ), and $50 \mathrm{mM}$ Tris- $\mathrm{HCl}$ buffer ( $\mathrm{pH}$ 8.0-12.0)] and activities were assayed using bovine casein as described above. The $\mathrm{pH}$ stability of the enzyme was assayed by measuring the remaining activity after incubation with a given buffer for $2 \mathrm{~h}$ with continuous shaking.

\subsection{Kinetic parameters of cucumisin}

Kinetic parameters of the recovered cucumisin with bovine casein as substrate were determined as described in the standard assay conditions under different substrate concentrations (0.0-15 $\mathrm{mgmL}^{-1}$ ). Kinetic data (apparent $V \max$ and $\mathrm{Km}$ values) were obtained by non-linear regression using the Michaelis-Menten equation in the SigmaPlot 12 software. All the reactions were carried out in triplicates.

\subsection{Effect of inhibitors on the cucumisin activity}

The effect of selective inhibitors (PMSF (0.5 mM), EDTA (2 mM), EGTA $(2 \mathrm{mM})$, iodoacetamide $(5 \mathrm{mM})$ and pepstatin $(2 \mathrm{mM}))$ on activity of the recovered enzyme was determined by preincubating the enzyme with the different inhibitors at $37^{\circ} \mathrm{C}$ for $1 \mathrm{~h}$ to evaluate their influence on protease activity. Bovine casein as a substrate 

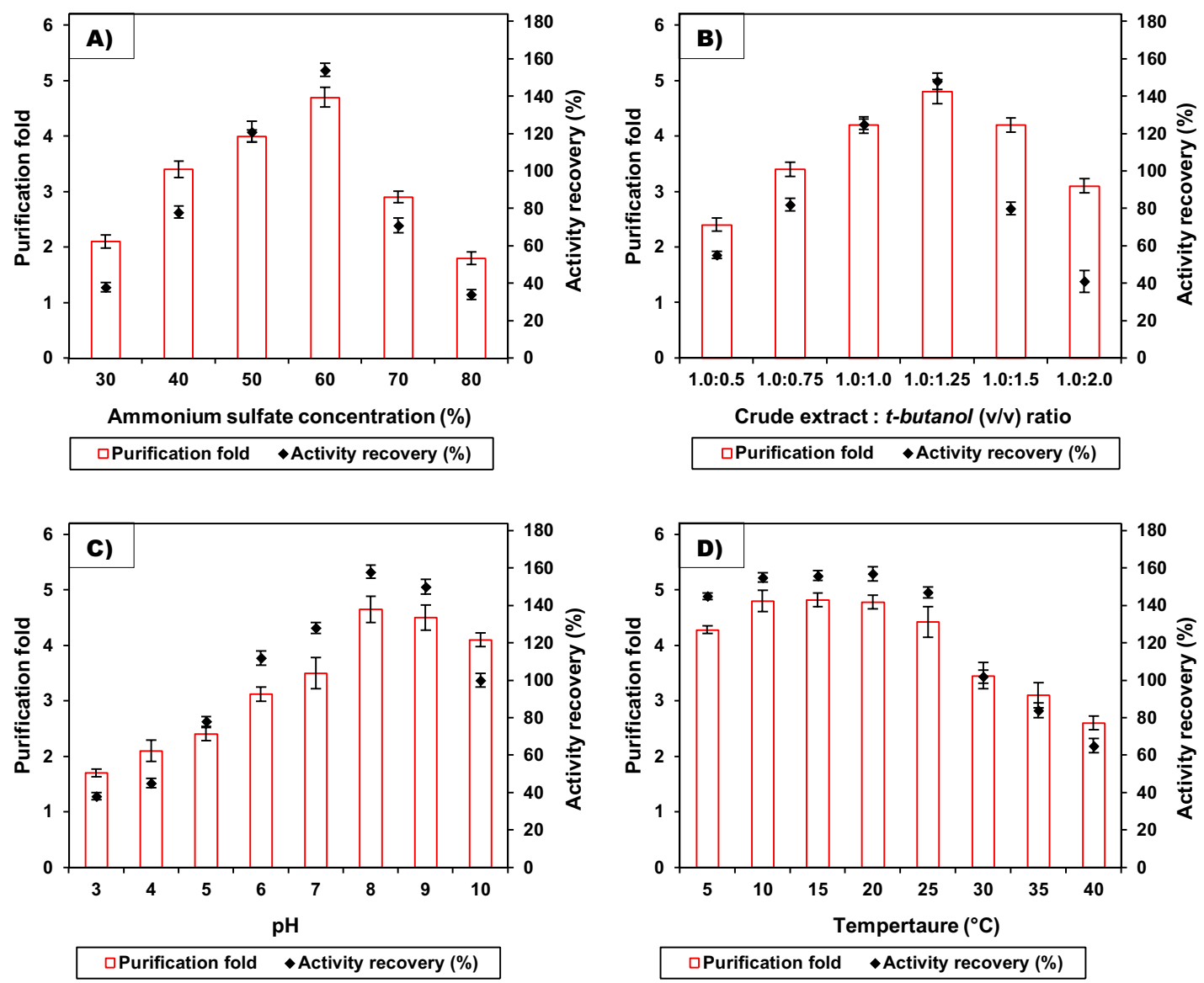

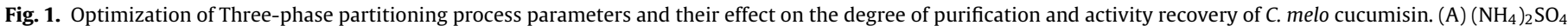

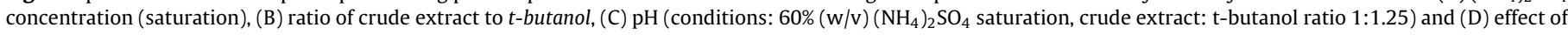
temperature variation from $5^{\circ} \mathrm{C}$ to $40^{\circ} \mathrm{C}$.

was then added and the residual caseinolytic activity was measured under standard assay condition. The activity of enzyme in the absence of inhibitors was considered as control (100\%).

\subsection{Effect of metal ions on cucumisin activity}

The effect of $\mathrm{NaCl}, \mathrm{KCl}, \mathrm{MgCl}_{2}, \mathrm{CaCl}_{2}, \mathrm{CoCl}_{2}, \mathrm{MnCl}_{2}, \mathrm{CdCl}_{2}, \mathrm{MgSO}_{4}$, $\mathrm{FeSO}_{4}, \mathrm{MnSO}_{4}$ and $\mathrm{ZnSO}_{4}$ on the recovered cucumisin activity was evaluated by its incubation with the metal ion $(5 \mathrm{mM})$ at $37^{\circ} \mathrm{C}$ for $1 \mathrm{~h}$, followed by determining the remaining activity using casein assay as described above. The enzyme activity assayed in the absence of metal ions was considered as control and defined as $100 \%$. Moreover, the half-life of the enzyme in the presence of $\mathrm{Ca}^{2+}$ ions was determined in the same way by mixing with enzyme in the concentration of $2.5,5$ and $10 \mathrm{mM}$, and then the mixture sample incubated at $35,40,45,50$ and $55^{\circ} \mathrm{C}$ for up to $3 \mathrm{~h}$. To determine the values of enzyme half-life, the residual activity was assessed at $30 \mathrm{~min}$ intervals over the total period of $180 \mathrm{~min}$ and the calculations were performed by the method first described by Yamane and co-workers [34]. The values are means of three independent experiments.

\subsection{Storage stability}

Stability at storage at $4{ }^{\circ} \mathrm{C}, 25^{\circ} \mathrm{C}$ and $-20^{\circ} \mathrm{C}$ of the recovered cucumisin for three weeks was assayed and the results were expressed as milk-clotting activity units $(\mathrm{U} / \mathrm{mL})$. In addition, to study the effect of storage on the enzyme autolysis and denaturation, a glycine SDS-PAGE analysis was performed following the conditions described above. For that, after each point-time of the storage stability test (sub-samples of the recovered enzyme stored in tubes, corresponding to $0,2,6,8,10,12,14,18$ and 20 days at $-20^{\circ} \mathrm{C}$ ), a fraction of the protease was subsequently denatured by mixing at a ratio of $1: 1$ with the Laemmli buffer containing $0.125 \mathrm{M}$ Tris- $\mathrm{HCl}$ (pH 6.8), 20\% glycerol, 4\% SDS, $2 \% \beta$-MCE and $0.02 \%$ bromophenol blue. The fractions were then heated for 5 min in a bath water at $95^{\circ} \mathrm{C}$ and stored at $-20^{\circ} \mathrm{C}$ until loading of all samples ( 9 points of the kinetic) on the same global gel.

\section{Results and discussion}

\subsection{Three-phase partitioning}

Numerous parameters may affect the TPP bioseparation technique and ammonium sulfate, $t$-butanol concentration, temperature, and $\mathrm{pH}$ were considered to be the critical factors. Therefore, the optimization of these mentioned parameters was conducted for direct one step partitioning of cucumisin. The results reported in Fig. 1a-d are the averages of at least three measurements using a starting protein concentration of $39.7 \mathrm{mg} / \mathrm{mL}$ (containing $28.1 \mathrm{U} / \mathrm{mL}$ of the protease activity).

\subsubsection{Effect of salt}

Different salts (cosmotropic, chaotropic and neutral) were investigated in TPP systems (Table 1). In the present study, $\left(\mathrm{NH}_{4}\right)_{2} \mathrm{SO}_{4}$ was found and used as phase forming salt that is often provided the most effective effect on the protein partitioning process $[4,28,35]$. Salting out of proteins with $\left(\mathrm{NH}_{4}\right)_{2} \mathrm{SO}_{4}$ not only 

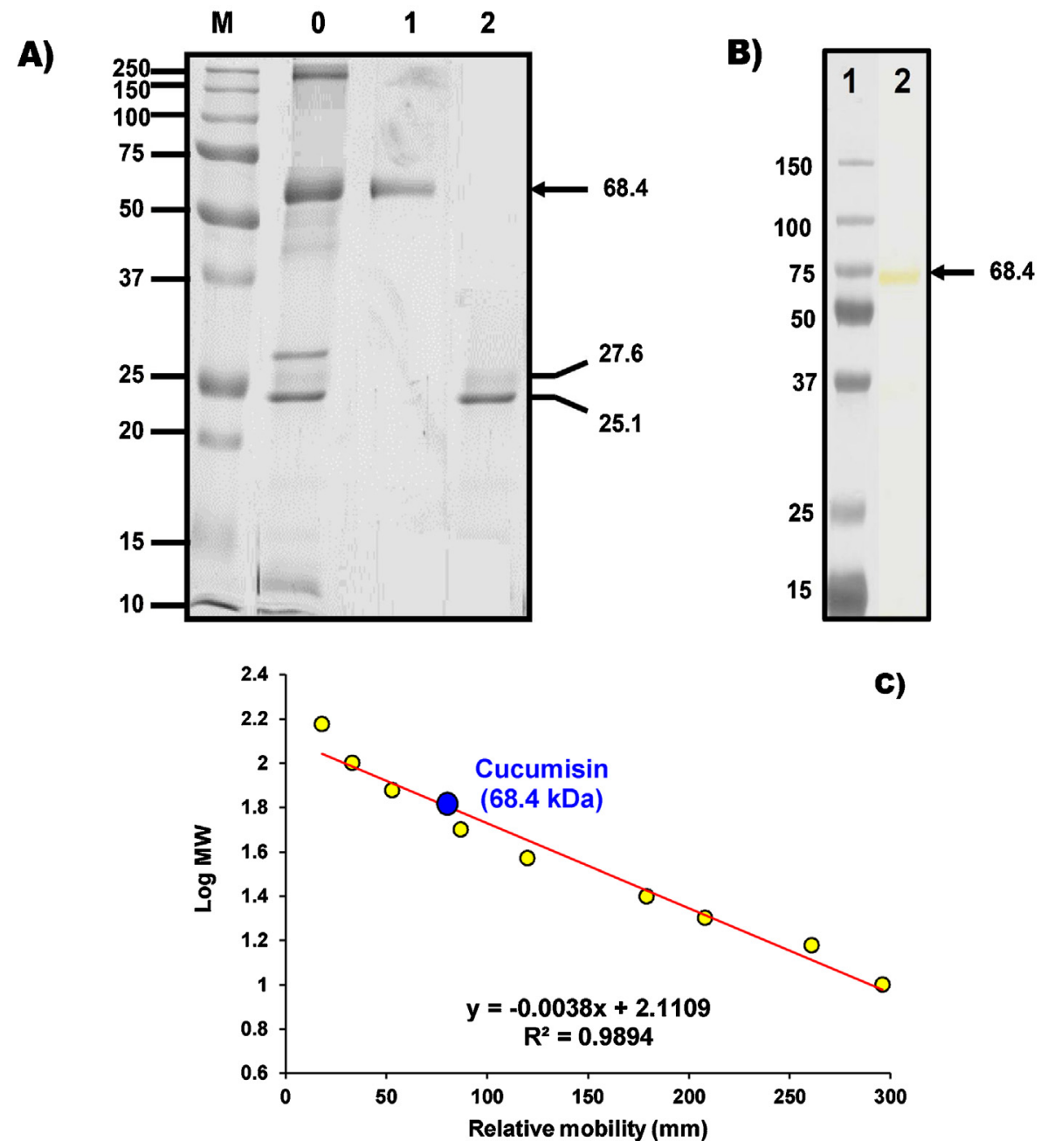

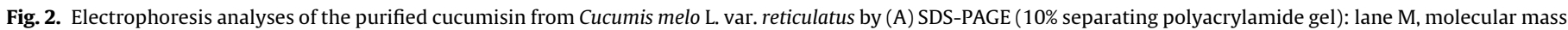

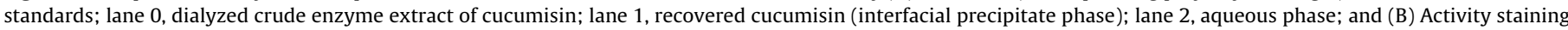

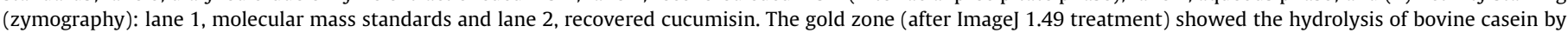

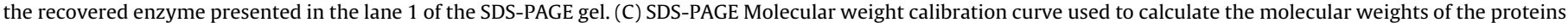
(molecular masses vs. their relative mobility).

purify the proteins but also concentrate them into one of the phases according to net charge of the proteins and concentration of this salt in the system. Therefore, $\left(\mathrm{NH}_{4}\right)_{2} \mathrm{SO}_{4}$ saturation is a very critical parameter in TPP as it is responsible for protein-protein interaction and precipitation. So it has been optimized for the efficient recovery of cucumisin. The results (Fig. 1a) showed that the best partitioning was obtained at $60 \%(\mathrm{w} / \mathrm{v})$ saturation giving the maximum fold purification of 4.7 -fold along with $154 \%$ recovery of cucumisin activity in the interfacial phase. A similar saturation was reported for the purification of $\beta$-galactosidase from chick pea [35]. With an increase in $\left(\mathrm{NH}_{4}\right)_{2} \mathrm{SO}_{4}$ concentration from $30 \%$ to $60 \%(\mathrm{w} / \mathrm{v})$ the purification fold degree and activity recovery values were increased significantly. Further increase in $\left(\mathrm{NH}_{4}\right)_{2} \mathrm{SO}_{4}(>60 \%)$ causes a reduction in the selectivity of extraction and also degree of purification as already reported [36]. This may be due to the irreversible denaturation of the protein. At the lowest (30\%) and at the highest (80\%) salt saturations, very low percentage recoveries were found and are respectively $38 \%$ and $34 \%$. Thus, $60 \%$ salt saturation was sufficient enough to concentrate the cucumisin in the interfacial layer. The findings showed also that during the TPP process, an enhancement of the activity of enzyme may be also possible. This is due to the protective phenomenon that the increased flexibility of enzyme can lead to higher catalytical activity in TPP process [5,25]. Accord- ingly, earlier studies reported an increase in the catalytic activity and yield of several proteases [4,28,37-39]. It was suggested that, the salting out of a protein in TPP system is depended to ionic strength effects, kosmotropy, osmotic stressor, exclusion crowding agent and binding of sulfate ion to cationic sites of a protein $[5,25]$.

\subsubsection{Effect t-butanol}

A major difference between conventional salting out procedure and TPP is the addition of C4 alcohols like $t$-butanol, which is a nonionic kosmotrope that is very soluble and acting as a differentiating solvent. $t$-Butanol has been selected in this study since it gives the highest recovery (Table 1) and due to its several advantages over other solvents as reported to deliver best results for separation $[4,5,38,39]$. $t$-Butanol is miscible in water, but after the addition of enough $\left(\mathrm{NH}_{4}\right)_{2} \mathrm{SO}_{4}$, the solution can make three-phase layers and remove lipids, phenolics, pigments and enzyme inhibitors efficiently. It does not easily permeate inside the folded protein molecules and hence does not cause denaturation due to its size and branched structure [25]. The results of the effect of crude extract to $t$-butanol ratio for cucumisin partitioning are highlighted in Fig. $1 \mathrm{~b}$. The addition of $t$-butanol to $\left(\mathrm{NH}_{4}\right)_{2} \mathrm{SO}_{4}$ precipitated cucumisin in the interfacial phase and the highest recovery (148\%) correspond- 
Table 2

Recovery profile and overall purification of cucumisin from fresh Cucumis melo var. reticulatus by Three-phase partitioning .

\begin{tabular}{|c|c|c|c|c|c|}
\hline Purification step & Total protein (mg) & Total activity (U) & Specific activity (U/mg) & Purification fold & Recovery (\%) \\
\hline Crude extract & 39.7 & 28.1 & 0.71 & 1.00 & 100 \\
\hline TPP aqueous phase & 23.0 & 0.57 & 0.02 & 0.03 & 2.02 \\
\hline Interfacial phase of TPP & 13.4 & 43.7 & 3.26 & 4.61 & 156 \\
\hline
\end{tabular}

a The ammonium sulfate $(60 \%, \mathrm{w} / \mathrm{v})$ was added to the dialyzed crude extract of $C$. melo juice and then pH was adjusted to $\mathrm{pH} 8.0$. This was followed by the addition of

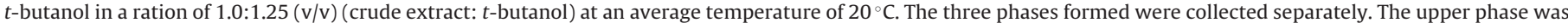

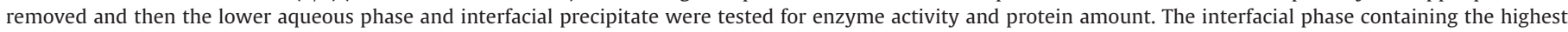
proteolytic activity was used for the overall characterization of cucumisin.

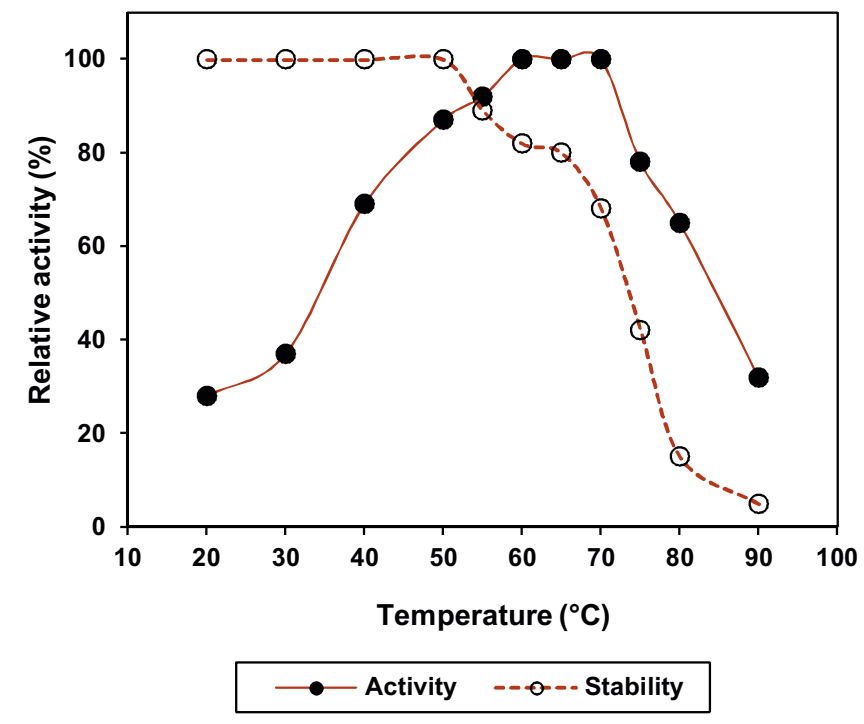

Fig. 3. Effect of temperature on the activity and the stability of $C$. melo cucumisin. Activity was done at defined temperatures $\left(20-90^{\circ} \mathrm{C}\right)$ by using bovine casein. Thermal stability was done after $2 \mathrm{~h}$ incubation at the indicated temperatures.

ing to a purification fold of 4.8 was obtained at the ratio of 1.0:1.25. With subsequent increase in crude extract to t-butanol ratio the activity recovery decreased. From $1.0: 0.5$ to $1.0: 1.0$ ratios, there is less\% recovery and the amounts does not adequately synergize with $\left(\mathrm{NH}_{4}\right)_{2} \mathrm{SO}_{4}[25,36]$. At higher amount it is likely to cause protein denaturation as reported in many earlier studies [4,25]. From these findings, the ratio of crude extract to $t$-butanol of 1.0:1.25 was selected for investigating the effect of $\mathrm{pH}$ value on the TPP system.

\subsubsection{Effect $p H$}

As already mentioned, the $\mathrm{pH}$ of medium is another important parameter affecting the TPP system as it causes ionization of acidic or basic amino acids present in the protein [25]. It was reported that TPP systems usually sharply change around the isoelectric point ( $\mathrm{pI}$ ) of the proteins and it's efficiently depend on this parameter. The distribution and partitioning of proteins in TPP systems change with $\mathrm{pH}$ due to electrostatic interactions between phases and charged proteins $[5,28]$. The behavior of the effect of crude extract with different $\mathrm{pH}$ values ranging from 3 to 10 on the partitioning of cucumisin is illustrated in Fig. 1c. Cucumisin had partitioned selectively to the interfacial phase and the system gave a maximum 4.65 -fold purification and $158 \%$ activity recovery of the protease at $\mathrm{pH}$ 8.0. TPP of cucumisin at $\mathrm{pH} 8.0$ selectively removes most of this protease from aqueous mixture into the interfacial phase. Thus, the increased yield at $\mathrm{pH} 8.0$ could be due to the better conformational stability of cucumisin towards t-butanol at this $\mathrm{pH}$. We can hypothesized that recovery of cucumisin in the interfacial phase may be due to the development of positive charge on the surface of the protease that facilitates binding of $\left(\mathrm{NH}_{4}\right)_{2} \mathrm{SO}_{4}$ to the cationic sites, thus greatly enhancing the effect of electrostatic screening and minimizing the electrostatic repulsion between like-charged protein molecules or protein-stabilized emulsion drops. Moreover, it is well known that proteins tend to precipitate most readily at their $\mathrm{pI}$. A standard observation is that when the system $\mathrm{pH}$ is below the $\mathrm{pI}$ of the target protein, there is maximum precipitation or accumulation of protein in the middle phase, whereas, if the system $\mathrm{pH}$ is above the $\mathrm{pI}$, the target protein gets pushed to the aqueous phase. In agreement to this observation, the $\mathrm{p} I$ of the recovered cucumisin was 8.7. This finding is in accordance with an earlier study reporting that serine protease from melon may have a highly basic $\mathrm{pI}$ [40]. Finally, it can be stated from Fig. 1c that the purification efficiency was low in the acidic as well as neutral range as compared to the basic range.

\subsubsection{Effect of temperature}

Temperature is another important physical parameter that though does not seem to have any effect on amount of the recovered proteins but found to play a role in the enzyme configuration and overall stability [36]. The effect of temperature on partitioning behavior of cucumisin is given in Fig. 1d. Recovery of cucumisin was increased with an increase in the temperature from 5 to $20^{\circ} \mathrm{C}$. The maximum recovery and purification fold of $155-157 \%$ and 4.78 4.82 were found at $10-20^{\circ} \mathrm{C}$, respectively. A decrease in purification factor and activity at higher temperature (above $25^{\circ} \mathrm{C}$ ) may be due to thermal deactivation of enzyme. Probable reason behind this may be also, as already explained, at $10-20^{\circ} \mathrm{C}$ temperature, $t$ butanol imparts significant kosmotropic and crowding effects and enhances partitioning of cucumisin [36]. A similar result with zingibain, a milk-clotting enzyme, was reported using TPP [27]. By considering economic and operational feasibility, the temperature of $20^{\circ} \mathrm{C}$ was chosen as it is around room temperature. Furthermore, the requirement for low temperatures in the operation of TPP is favorable as the heat generated from the solvent or salt precipitation can be dissipated quicker, causing minimal protein denaturation.

\subsection{Overall TPP purification profile}

The overall purification profile of cucumisin from $C$. melo juice by conventional TPP is given in Table 2 . The protease has tendency to concentrate exclusively in the interfacial phase of the TPP system, which is probably related to its structure. The overall recovery parameters of cucumisin are $60 \%(\mathrm{w} / \mathrm{v})\left(\mathrm{NH}_{4}\right)_{2} \mathrm{SO}_{4}, 1.0: 1.25$ ratio of the crude extract to $t$-butanol at $\mathrm{pH} 8.0$ and temperature of $20^{\circ} \mathrm{C}$. These optimized parameters gave the highest recovery and purification fold of $156 \%$ and 4.61 , respectively. From these data, it seems that TPP is quietly appropriate for fast recovery of proteases and namely milk-clotting enzymes [5], since it is economic, cheap and in one step the protease can be purified with high recovery. In addition, this process leads to simultaneous activation of enzyme explaining the apparently higher observed yield values $(>100 \%)$. This may be as already reported a result of increased flexibility in the enzyme molecule [41]. Several studies are available on the partitioning and purification of different proteases from various sources with TPP such as ficain [4], zingibain [27,28], papain [39], alkaline proteases [38] and proteases of Calotropis procera [37] and 


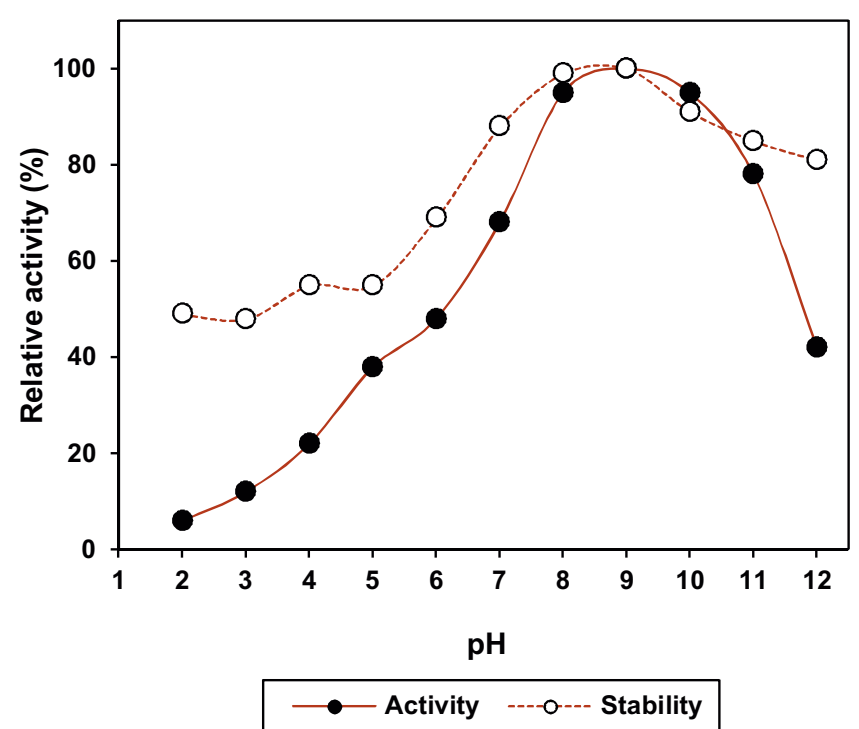

Fig. 4. Effect of $\mathrm{pH}$ on the activity of $C$. melo cucumisin. Activity was done after incubation at pHs from 2.0 to 12.0 [( $50 \mathrm{mM}$ citrate buffer ( $\mathrm{pH} 2.0-5.0), 50 \mathrm{mM}$ sodium phosphate buffer ( $\mathrm{pH}$ 6.0-7.0), and $50 \mathrm{mM}$ Tris- $\mathrm{HCl}$ buffer ( $\mathrm{pH} 8.0-12.0)]$ and activities were assayed using bovine casein.

all of them were reported to be remarkably increased their activity and yield. For example, we have recently reported that when TPP was applied to a milk-clotting enzyme, zingibain, a yield of approximately $215 \%$ with 14.9 -fold purity was obtained [28].

This report shows that under optimized conditions, TPP is a useful tool for the recovery of $C$. melo cucumisin in comparison to the earlier reported purification protocols summarized in Table 3. The earlier protocols include often more than two chromatographic steps. In addition, the obtained yields range from 5 to $54 \%$ only, in comparison to the recovery yield of $156 \%$ obtained in this study using TPP as a single purification step.

\subsection{Characterization of the purified cucumisin}

\subsubsection{SDS-PAGE analysis}

The purity of the cucumisin recovered from the juice of $C$. melo using TPP was confirmed by the SDS-PAGE profile (Fig. 2a). The protease was nearly homogeneous with an apparent molecular weight of $68.4 \mathrm{kDa}$ (Fig. 2a,c). A finding in agreement with the well characterized cucumisin from C. melo [42] and with other cucumisin-like serine proteases $[11,20]$. In comparison to cucumisins purified from different cultivars of $C$. melo, Table 3 summarized some results. The Mw of the recovered protease was also nearly similar to those of religiosin B and streblin, milk-clotting serine proteases from Ficus religiosa [43] and Streblus asper [10], respectively. The Mw of plant serine proteases, so far known, were reported to vary from 19 to $110 \mathrm{kDa}$ and the majority fall in the range of $60-80 \mathrm{kDa}$ [6]. The analysis of the aqueous phase showed the presence of two protein bands with Mw of $\sim 25.1$ and $\sim 27.6 \mathrm{kDa}$. These two proteins, with no proteolytic activity, are likely to correspond to contaminants or fragments of the target enzyme. Finally, casein activity staining (Fig. 2b) confirmed the proteolytic nature of the recovered protease, where the digested substrate appeared as well-resolved protein band, corresponding to the position of the enzyme in gel.

\subsubsection{Effect of temperature on the activity and stability of cucumisin}

The effect of temperature on cucumisin activity and stability was studied in the temperature range of $20-90{ }^{\circ} \mathrm{C}$ (Fig. 3). The protease was very active over a broad temperature range of $40-80^{\circ} \mathrm{C}$

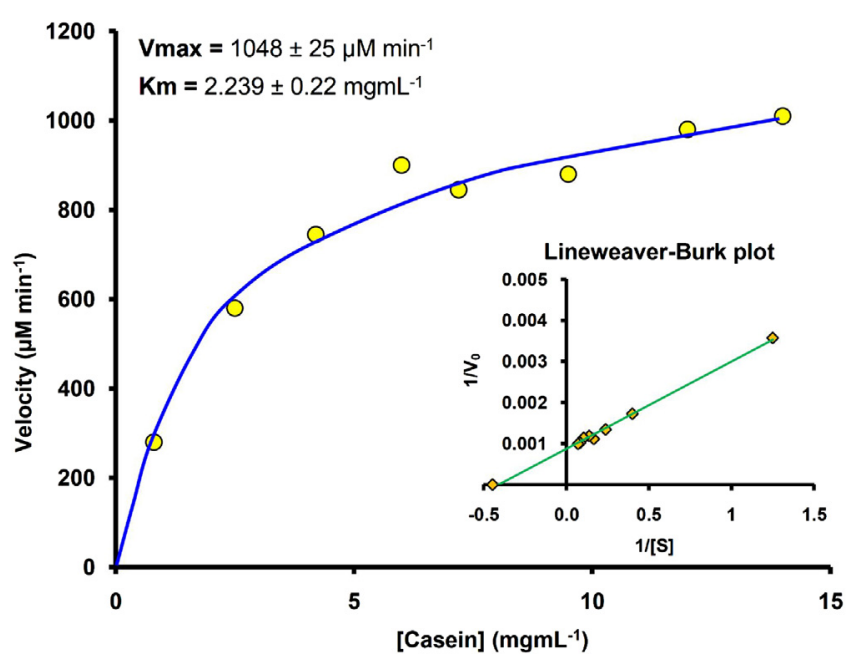

Fig. 5. Kinetics (Michaelis-Menten and Lineweaver-Burk plot) of the purified cucumisin from Cucumis melo L. var. reticulatus using Three Phase Partitioning. Data are averages of three independent experiments.

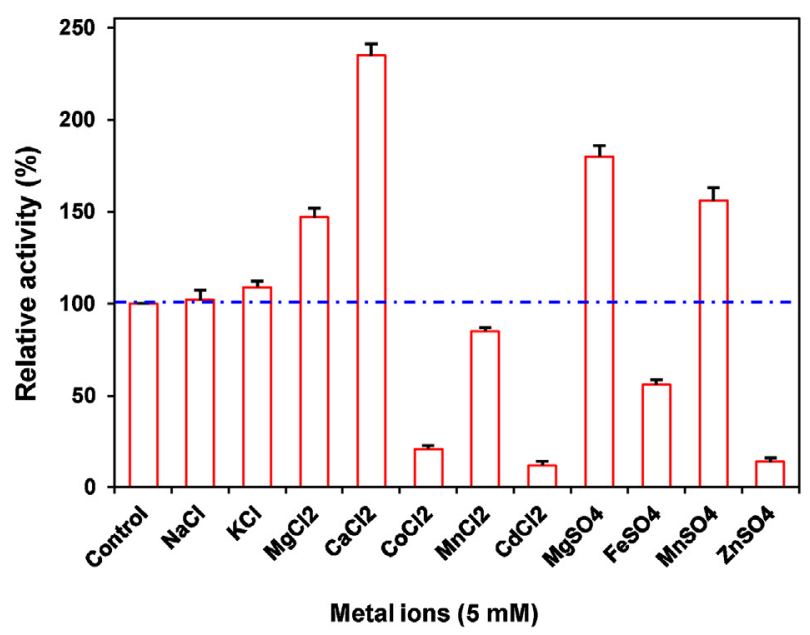

Fig. 6. Effect of some metal ions on the activity of $C$. melo cucumisin. Enzyme activity was evaluated by incubating recovered cucumisin in presence of various metal ions at $37^{\circ} \mathrm{C}$ for $1 \mathrm{~h}$ using bovine casein as substrate. The enzyme activity assayed in the absence of any metal ion was considered as control and defined as $100 \%$. Data are averages of three independent experiments \pm standard deviations.

with an optimum temperature of $60-70^{\circ} \mathrm{C}$. Even at high temperatures it seems that the protease retains more than $65 \%$ of its activity at $80^{\circ} \mathrm{C}$. The findings are in line with previous reports (Table 3) for cucumisin $[12,42]$. The results are also comparable to those of plant serine milk-clotting proteases, namely Dubiumin [44], Streblin [10], Benghalensin [14] and Religiosin B [43]. Thermal stability results indicated that the protease is stable between the temperatures' range of $20-65^{\circ} \mathrm{C}$. The enzyme retained about $68 \%$ of its initial activity after $2 \mathrm{~h}$ incubation at $70^{\circ} \mathrm{C}$.

\subsubsection{Effect of $p H$ on the activity and stability of cucumisin}

The recovered protease was found active over a broad range of $\mathrm{pH}$. It retained proteolytic activity in the range of $\mathrm{pH} 7.0-11.0$, with optimum activity at pH 9.0 (Fig. 4). As expected and in agreement to the literature concerning subtilisin/cucumisin-like plant serine proteases (Table 3 ), the recovered cucumisin is more active in the neutral and alkaline range as compared to the acidic range characterized by the lowest activity. An optimum $\mathrm{pH}$ in the range of $8-10$ was reported $[19,21]$. These findings are comparable to those of well known milk-clotting enzymes [10,15,28,44]. 
Table 3

Comparison of different purification processes from literature for cucumisin purification.

\begin{tabular}{|c|c|c|c|c|c|c|c|c|}
\hline Source & Plant parts & $\begin{array}{l}\text { Purification method } \\
\text { steps }\end{array}$ & MW (kDa) & Optimum pH & $\begin{array}{l}\text { Optimum } \\
\text { Temp. }\left({ }^{\circ} \mathrm{C}\right)\end{array}$ & $\begin{array}{l}\text { Purification } \\
\text { (fold) }\end{array}$ & $\begin{array}{l}\text { Recovery } \\
(\%)\end{array}$ & Refs. \\
\hline $\begin{array}{l}\text { C. melo L. var. } \\
\text { Prince }\end{array}$ & Sarcocarp & $\begin{array}{l}\text { Ammonium sulfate } \\
\text { precipitation (60\%) } \\
\text { CM-cellulose Sephadex } \\
\text { G-75 }\end{array}$ & 50 & 10 & 70 & 7.2 & 54 & [12] \\
\hline $\begin{array}{l}\text { C. melo L. var. } \\
\text { Prince }\end{array}$ & Sarcocarp & $\begin{array}{l}\text { Ammonium sulfate } \\
\text { precipitation }(60 \%) \\
\text { Sephadex }(1,2,3) \\
\text { CM-cellulose }\end{array}$ & 67 & 10,5 & 70 & 6.1 & 12 & [42] \\
\hline $\begin{array}{l}\text { C. melo L. var. } \\
\text { inodorus Naud }\end{array}$ & Juice & $\begin{array}{l}\text { Ammonium sulfate } \\
\text { precipitation }(70 \%) \\
\text { CM-cellulose } \\
\text { Sephadex }(1,2)\end{array}$ & 50 & 11 & - & 38 & 5 & [60] \\
\hline $\begin{array}{l}\text { C. melo L. var. } \\
\text { Prince }\end{array}$ & Juice & $\begin{array}{l}\text { Ammonium sulfate } \\
\text { precipitation }(60 \%) \\
\text { CM-Sepharose }(1,2)\end{array}$ & 67 & - & - & 7.2 & 28 & [20] \\
\hline $\begin{array}{l}\text { C. melo var. } \\
\text { reticulatus } \\
\text { Naud }\end{array}$ & Sarcocarp & $\begin{array}{l}\text { DEAE-cellulose } \\
\text { Ammonium sulfate } \\
\text { precipitation (60\%) } \\
\text { CM-Sepharose }\end{array}$ & 62 & 10 & - & - & 39 & [61] \\
\hline $\begin{array}{l}\text { C. melo var. } \\
\text { reticulatus }\end{array}$ & Juice & $\begin{array}{l}\text { Three phase } \\
\text { partitioning }\end{array}$ & 68.4 & $8.0-9.0$ & 70 & 4.61 & 156 & Present study \\
\hline
\end{tabular}

Table 4

Half-life of the recovered cucumisin in the presence of calcium at different concentrations ${ }^{\mathrm{a}}$.

\begin{tabular}{|c|c|c|c|c|c|}
\hline \multirow[t]{2}{*}{ Sample } & \multicolumn{5}{|c|}{ Half life } \\
\hline & $35^{\circ} \mathrm{C}$ & $40^{\circ} \mathrm{C}$ & $45^{\circ} \mathrm{C}$ & $50^{\circ} \mathrm{C}$ & $55^{\circ} \mathrm{C}$ \\
\hline Control & $123 \mathrm{~min}$ & $104 \mathrm{~min}$ & $87 \mathrm{~min}$ & $64 \mathrm{~min}$ & $32 \mathrm{~min}$ \\
\hline $\mathrm{Ca}^{2+}(2.5 \mathrm{mM})$ & $141 \mathrm{~min}$ & $117 \mathrm{~min}$ & $96 \mathrm{~min}$ & $78 \mathrm{~min}$ & $49 \mathrm{~min}$ \\
\hline $\mathrm{Ca}^{2+}(5.0 \mathrm{mM})$ & $164 \mathrm{~min}$ & $128 \mathrm{~min}$ & $106 \mathrm{~min}$ & $89 \mathrm{~min}$ & $68 \mathrm{~min}$ \\
\hline $\mathrm{Ca}^{2+}(10 \mathrm{mM})$ & $178 \mathrm{~min}$ & $167 \mathrm{~min}$ & $145 \mathrm{~min}$ & $101 \mathrm{~min}$ & $77 \mathrm{~min}$ \\
\hline
\end{tabular}

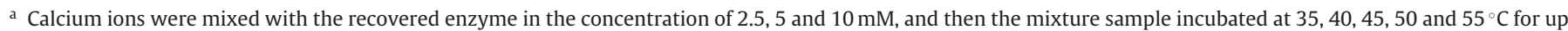
to $3 \mathrm{~h}$. The values are means of three independent experiments.

\subsubsection{Kinetic parameters}

The kinetic parameters $\mathrm{Km}$ and Vmax were determined by measuring the activity of the recovered cucumisin using casein as substrate (Fig. 5). The parameters were determined by fitting experimental data to Michaelis-Menten model and were calculated from Lineweaver-Burk graph as $2.24 \pm 0.22 \mathrm{mgmL}^{-1}$ and $1048 \pm 25 \mu \mathrm{Mmin}^{-1}$, respectively. The results reported in literature showed that the kinetic constants had varying values depending on the source of the enzyme and used substrate $[19,23,45]$. The estimated $\mathrm{Km}$ indicated the affinity of enzyme toward the substrate. Vmax is an indication of the catalytic activity which is usually desired to be as high as possible.

\subsubsection{Effect of metallic ions and inhibitors on the recovered cucumisin}

Various metal ions $(5 \mathrm{mM})$ were tested for their effects on cucumisin activity (Fig. 6). The recovered cucumisin was found to be highly stable against numerous metal ions and its activity was significantly enhanced by $\mathrm{Ca}^{2+}, \mathrm{Mg}^{2+}$, and $\mathrm{Mn}^{+2}$ and slightly by $\mathrm{Na}^{+}$ and $\mathrm{K}^{+}$. As per our expectations, $\mathrm{Ca}^{2+}$ increased the activity of the enzyme by 2.35 -folds, reflecting significant effect. Similar results of effective $\mathrm{Ca}^{2+}$ concentration as stimulator of protease activity have been reported for several milk-clotting enzymes [43,46]. Since the protease was found to be highly active in the presence of $\mathrm{Ca}^{2+}$, we have performed half-life tests using different concentrations of $\mathrm{Ca}^{2+}$ and temperatures (Table 4 ). The results showed that halflives $\left(t_{1 / 2}\right)$ of enzyme preparations at different temperatures clearly depicted the enzyme stability as a function of temperature. Stability of enzymes at higher temperatures for prolonged periods in the presence of $\mathrm{Ca}^{2+}$ is of great concern for their suitability in cheese-making. The effect of the concentration of $\mathrm{Ca}^{2+}$ on milk-
Table 5

Effect of some usual inhibitors on cucumisin activity.

\begin{tabular}{lllc}
\hline Inhibitor class & Inhibitor name & Concentration & $\begin{array}{l}\text { Residual } \\
\text { proteolytic } \\
\text { activity }(\%)^{\mathrm{a}}\end{array}$ \\
\hline None (control) & None & - & 100 \\
Metalloprotease & EDTA & $2.0 \mathrm{mM}$ & 68 \\
& EGTA & $2.0 \mathrm{mM}$ & 72 \\
Cysteine protease & Iodoacetamide & $5.0 \mathrm{mM}$ & 98 \\
Serine protease & PMSF & $0.5 \mathrm{mM}$ & 7.04 \\
Aspartic acid protease & Pepstatin & $2.0 \mathrm{mM}$ & 97 \\
\hline
\end{tabular}

a The values are means \pm standard deviation of three independent experiments Activities of cucumisin incubated without the inhibitors were treated as controls.

clotting has been reported in various studies [47] where a higher $\mathrm{Ca}^{2+}$ concentration results in a faster enzyme coagulation due to the combined effect of the increased $\mathrm{Ca}^{2+}$ ion activity and a drop in milk pH, leading to changes in cheese properties [48]. Finally, our findings showed clearly that the protease thermo-stability is to some extent dependent to $\mathrm{Ca}^{2+}$ which is in line with earlier studies $[49,50]$.

The protease was inactivated mostly by metal ions of first transition series such as $\mathrm{Co}^{2+}, \mathrm{Cd}^{2+}, \mathrm{Zn}^{2+}$ and $\mathrm{Fe}^{2+}$ to $21 \%, 12 \%, 14 \%$ and $56 \%$ of its originally activity, respectively. It is noteworthy that several plant subtilisins from different sources exhibit considerable differences of cucumisin-like activity in the presence of metal ions [6].

On the other hand, the influences of four types of inhibitors on the activity of the recovered cucumisin are given in Table 5 . The enzyme retained 68 and $72 \%$ of its activity when it was incubated in the presence of respectively $2 \mathrm{mM}$ EDTA and EGTA. These findings indicate that $\mathrm{Ca}^{2+}$ and $\mathrm{Mg}^{2+}$ ions are not essential for the proteolytic 

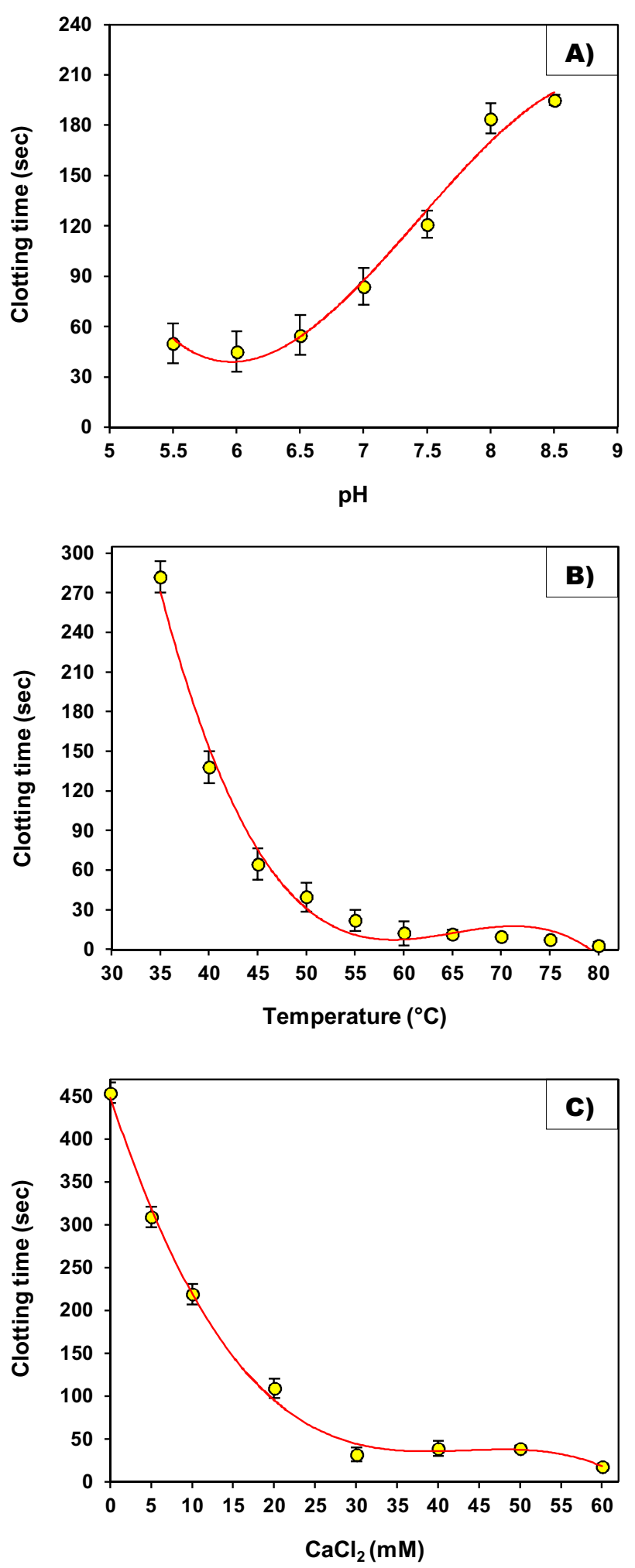

Fig. 7. Effects of $\mathrm{pH}$, temperature and salt concentration $\left(\mathrm{CaCl}_{2}\right)$ on milk-clotting activity of the recovered $C$. melo cucumisin. A) Effect of milk $\mathrm{pH}, \mathrm{B}$ ) temperature and $C$ ) concentration of $\mathrm{CaCl}_{2}$. Data are averages of three independent experiments \pm standard deviations of determined clotting time.

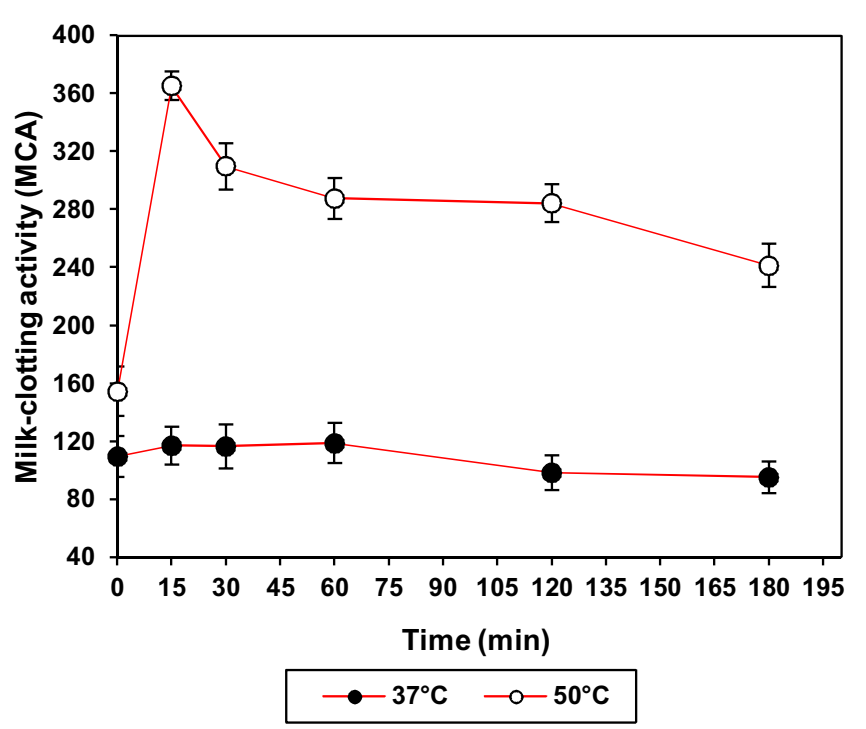

Fig. 8. Temperature and incubation time effects on milk-clotting activity (MCA) of the recovered $C$. melo cucumisin. The prepared milk was mixed with the recovered enzyme and incubated at two temperatures $\left(37\right.$ and $50^{\circ} \mathrm{C}$ ) and after different times the tubes were tested for MCA. Data are averages of three independent experiments \pm standard deviations.

activity of cucumisin but their presence may enhance efficiently its activity. In addition, the enzyme was remained active in the presence of iodoacetamide and pepstatin (98 and 97\% of residual activity). The residual cucumisin showed in agreement to previous studies $[11,12,43]$ a dramatic reduction in the presence of PMSF $(0.5 \mathrm{mM})$, revealing that this enzyme belongs to the class of serine proteases.

\subsubsection{Milk-coagulation: effects of $\mathrm{pH}$, temperature, $\mathrm{CaCl}_{2}$ and storage stability}

Milk coagulation is the primary step in the development of most dairy products and is known to takes place in two stages. In the first one, the enzyme converts k-casein in milk to para-casein, while in the second stage, para-casein in the presence of $\mathrm{Ca}^{2+}$ ions gives a firm clot [51]. Therefore, it is a common practice to add $\mathrm{CaCl}_{2}$ in milk to get firm clot in cheese manufacture. Other divalent cations such as magnesium are also known to cause coagulation. Thus, the milk-clotting properties of cucumisin are important characteristics to consider before any potential application in the food industry, such as cheese production.

In Fig. 7 are summarized the effects of $\mathrm{pH}$, temperature and concentration of $\mathrm{CaCl}_{2}$ of milk on the clotting time using the recovered cucumisin. The results show that milk-clotting time is dependent on these parameters. Milk-clotting times increased (thus milkclotting activity decreased) by increasing $\mathrm{pH}$ from 5.5 to 8.5 and the best and stable clotting times (giving the best MCA) were between pH 5.5 and 6.5 (Fig. 7a). Similar findings were reported by previous studies [52,53]. The evolution of milk-clotting time between temperatures of 35 and $80^{\circ} \mathrm{C}$ at pH 6.4 is given on Fig. 7b. It clearly shows that the clotting time decreased as temperature increased and followed a decay curve up to $55^{\circ} \mathrm{C}$ and decreased from $282 \mathrm{~s}$ at $35^{\circ} \mathrm{C}$ to $22 \mathrm{~s}$ at $55^{\circ} \mathrm{C}$ and finally $7 \mathrm{~s}$ at $75^{\circ} \mathrm{C}$. These results agree to those of proteolytic activities presented above. A progressive reduction in plant milk-clotting enzymes coagulation times as temperature increases from 30 to $50^{\circ} \mathrm{C}$ has been reported by previous studies [52]. Similar clotting-time profile up to $60{ }^{\circ} \mathrm{C}$ in artichoke flower and Balanites aegyptiaca extracts were reported by [54] and [53], respectively. In addition, as depicted in Fig. 8, the cucumisin was found highly stable at $37^{\circ} \mathrm{C}$ and slightly at $55^{\circ} \mathrm{C}$ when incubated for a period of $3 \mathrm{~h}$. 


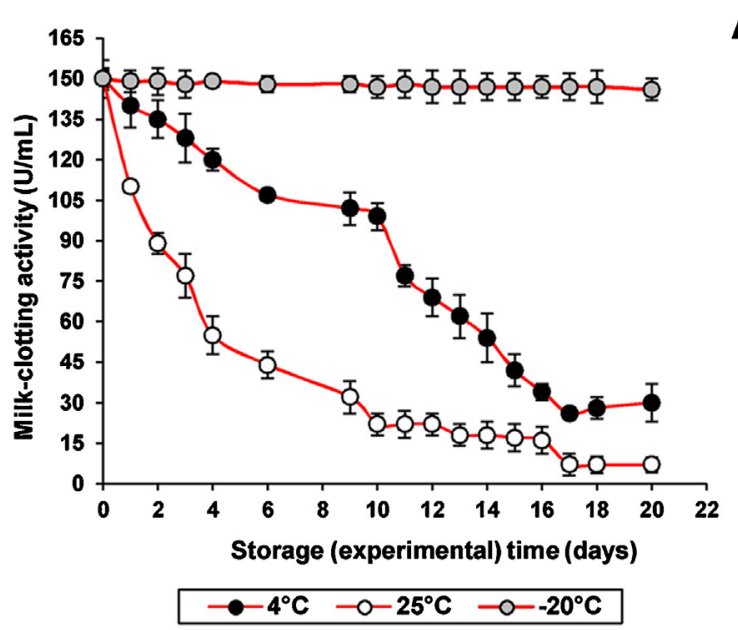

A)

B)

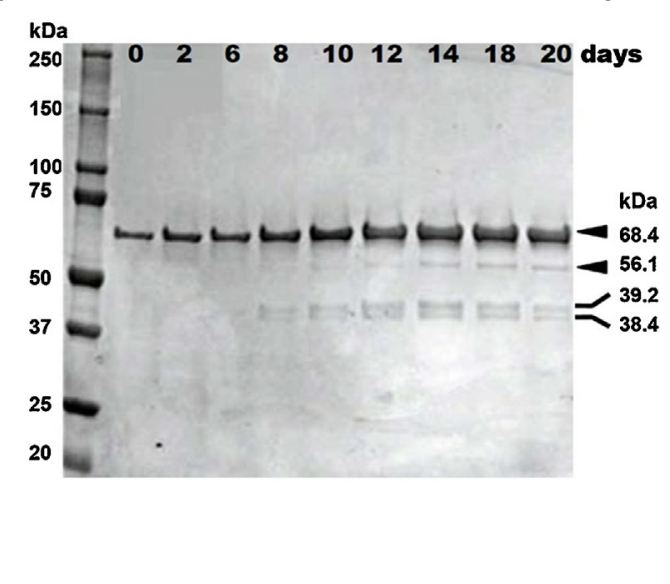

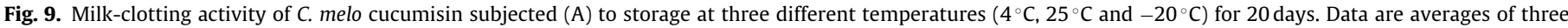

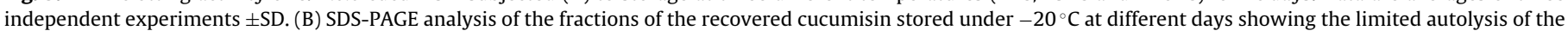
protease.

Otherwise, as discussed above, $\mathrm{CaCl}_{2}$ is usually added to milk to improve the milk coagulation. However, it is also documented that the addition of high concentrations of calcium chloride can reduce the $\mathrm{pH}$ of milk, resulting in a decreased aggregation rate and possible proteolytic inactivation [55]. Therefore, the effect of $\mathrm{CaCl}_{2}$ concentrations on milk-clotting times of cucumisin is given in Fig. 7c. The lowest clotting times were observed between 30 and $50 \mathrm{mM}$ of $\mathrm{CaCl}_{2}$. Cucumisin activity increased with increase in $\mathrm{CaCl}_{2}$ concentration, until a plateau is reached between 30 and $60 \mathrm{mM}$ of this salt, above which the enzyme activity remained almost constant suggesting that the enzyme got fully saturated at this concentration. Similar results were reported for other clotting plant enzymes [56,57].

After the evaluation of the above parameters, the enzyme was also tested for its stability after storage during 3 weeks at three different temperatures, $\left(-20^{\circ} \mathrm{C}, 4^{\circ} \mathrm{C}\right.$ and $\left.25^{\circ} \mathrm{C}\right)$ and the results of milk-clotting activity are highlighted in Fig. 9. As depicted in the graph (Fig. 9a), the recovered cucumisin retained $98.7 \%, 66 \%$ and $14.6 \%$ of its activity after being kept 10 days at $-20,4$ and $25^{\circ} \mathrm{C}$, respectively. After three weeks of storage, a loss of 95.4 and $80 \%$ were observed for the protease stored at 25 and $4{ }^{\circ} \mathrm{C}$, respectively. This might be due to protein-protein interaction [58], to autolysis $[4,28]$ or to molecular rearrangements in protein structure [59]. Furthermore, proteases are prone to autodigestion and the extent of autolysis depends on the enzyme concentration, $\mathrm{pH}$, incubation time, temperature and type of activator if any. On the other hand, the protease stored at $-20^{\circ} \mathrm{C}$ lost only $3 \%$ of its milk-clotting activity. This enhanced stability is probably a result of the prevention of autolysis by freezing. To assess this statement, the proteolytic fractions of the same tested kinetic points were subjected to SDS-PAGE (Fig. 9b). It can be clearly seen that cucumisin still intact during under freezing at $-20^{\circ} \mathrm{C}$ and the native fraction of $68.4 \mathrm{kDa}$ did not change even after 10 or 20 days. But we assist after 8 days of storage with the appearance of slight protein bands at 56.1, 39.2 and $38.4 \mathrm{kDa}$. They may be the residual fragments of the little intact protease cleaved during storage. These findings suggest that the recovered cucumisin might be preserved at $4{ }^{\circ} \mathrm{C}$ for a short storage of 5 days, whereas a longer life may be obtained by storage at $-20^{\circ} \mathrm{C}$.

\section{Conclusion}

To our knowledge, this is the first report of purification of cucumisin from the juice of $C$. melo fruits using three phase par- titioning system. In spite of various methods which have been developed for separation and purification of this protease, we succeeded in this study to adopt TPP as a simple and fast purification procedure with high yield recovery (156\%). Extensive investigations are needed to fully explore the potential application of cucumisin in cheese-making.

\section{Conflict of interest}

The authors confirm that this article content has no conflicts of interest.

\section{References}

[1] S.V. Silva, T. Allmere, F. Xavier Malcata, A. Andrén, Int. Dairy J. 13 (2003) $559-564$.

[2] M. Jacob, D. Jaros, H. Rohm, Int. J. Dairy Technol. 64 (2011) 14-33.

[3] A. Dhillon, K. Sharma, V. Rajulapati, A. Goyal, 7 - proteolytic enzymes A2, in: Ashok Pandey, S. Negi, C.R. Soccol (Eds.), Current Developments in Biotechnology and Bioengineering, Elsevier, 2017, pp. 149-173.

[4] M. Gagaoua, N. Boucherba, A. Bouanane-Darenfed, F. Ziane, S. Nait-Rabah, K. Hafid, H.-R. Boudechicha, Sep. Purif. Technol. 132 (2014) 461-467.

[5] M. Gagaoua, K. Hafid, Biosens. J. 5 (2016) 1-4.

[6] C.M. Antão, F.X. Malcata, Plant Physiol. Biochem. 43 (2005) 637-650.

[7] N.D. Rawlings, D.P. Tolle, A.J. Barrett, Biochem. J 378 (2004) 705-716.

[8] A. Schaller, Chapter 717 - plant subtilisins A2, in: Neil D. Rawlings, G. Salvesen (Eds.), Handbook of Proteolytic Enzymes, Academic Press, 2013, pp. 3247-3254

[9] M.A. Shah, S.A. Mir, M.A. Paray, Dairy Sci. Technol. 94 (2014) 5-16.

[10] P. Tripathi, R. Tomar, M.V. Jagannadham, Food Chem. 125 (2011) 1005-1012.

[11] M. Asif-Ullah, K.-S. Kim, Y.G. Yu, Phytochemistry 67 (2006) 870-875.

[12] M. Kaneda, N. Tominaga, J. Biochem. 78 (1975) 1287-1296.

[13] T. Uchikoba, M. Kaneda, Appl. Biochem. Biotechnol. 56 (1996) 325-330.

[14] A. Sharma, M. Kumari, M.V. Jagannadham, J. Agric. Food Chem. 57 (2009) $11120-11126$.

[15] K. Arima, T. Uchikoba, H. Yonezawa, M. Shimada, M. Kaneda, Phytochemistry 53 (2000) 639-644.

[16] M. Pande, V.K. Dubey, S.C. Yadav, M.V. Jagannadham, J. Agric. Food Chem. 54 (2006) 10141-10150.

[17] M. Kaneda, H. Ohmine, H. Yonezawa, N. Tominaga, J. Biochem. 95 (1984) $825-829$.

[18] H. Yamagata, T. Masuzawa, Y. Nagaoka, T. Ohnishi, T. Iwasaki, J. Biol. Chem. 269 (1994) 32725-32731.

[19] M. Kaneda, H. Yonezawa, T. Uchikoba, Biotechnol. Appl. Biochem. 22 (1995) 215-222.

[20] T. Uchikoba, H. Yonezawa, M. Kaneda, J. Biochem. 117 (1995) 1126-1130.

[21] T. Uchikoba, H. Yonezawa, M. Kaneda, Phytochemistry 49 (1998) 2215-2219.

[22] K. Arima, H. Yonezawa, T. Uchikoba, M. Shimada, M. Kaneda, Phytochemistry 54 (2000) 451-454.

[23] K. Arima, T. Uchikoba, H. Yonezawa, M. Kaneda, Chapter 718 - cucumisin, in: N.D. Rawlings, G. Salvesen (Eds.), Handbook of Proteolytic Enzymes, Academic Press, 2013, pp. 3254-3257.

[24] T. Senphan, S. Benjakul, Sep. Purif. Technol. 129 (2014) 57-63. 
[25] C. Dennison, Three-phase partitioning, in: H. Tschesche (Ed.), Methods in Protein Biochemistry, Walter de GruyterBerlin, Germany, 2011, pp. 1-5.

[26] S. Nait Rabah, F. Ziane, Mémoire De Fin De Cycle Ingénieur, Université Frères Mentouri Constantine 1, Constantine Algeria, 2016104.

[27] M. Gagaoua, K. Hafid, N. Hoggas, Data Brief 6 (2016) 634-639.

[28] M. Gagaoua, N. Hoggas, K. Hafid, Int. J. Biol. Macromol. 73 (2015) 245-252.

29] M.M. Bradford, Anal. Biochem. 72 (1976) 248-254.

[30] K. Arima, J. Yu, S. Iwasaki, Milk-clotting enzyme from Mucor pusillus var. Lindt, in: L.L. Gertrude, E. Perlmann (Eds.), Methods in Enzymology, Academic Press, 1970, pp. 446-459.

[31] U.K. Laemmli, Nature 227 (1970) 680-685.

[32] F.L. Garcia-Carreno, L.E. Dimes, N.F. Haard, Anal. Biochem. 214 (1993) 65-69.

[33] L. Nath, S. Dutta, Indian J. Pharm. Sci. 50 (1988) 125.

[34] T. Yamane, P. Sirirote, S. Shimizu, Biotechnol. Bioeng. 30 (1987) 963-969.

[35] Y.A. Duman, E. Kaya, Protein Expr. Purif. 91 (2013) 155-160.

[36] C. Dennison, R. Lovrien, Protein Expr. Purif. 11 (1997) 149-161.

[37] S. Rawdkuen, P. Chaiwut, P. Pintathong, S. Benjakul, Biochem. Eng. J. 50 (2010) $145-149$.

[38] S. Ketnawa, S. Benjakul, O. Martínez-Alvarez, S. Rawdkuen, Sep. Purif. Technol. 132 (2014) 174-181.

[39] P. Chaiwut, P. Pintathong, S. Rawdkuen, Process Biochem. 45 (2010) $1172-1175$.

[40] K. Noda, M. Koyanagi, H.C. Kamiya, J. Food Sci. 59 (1994) 585-587.

41] G.M. Rather, M.N. Gupta, Int. J. Biol. Macromol. 60 (2013) 134-140.

[42] H. Yamagata, S. Ueno, T. Iwasaki, Agric. Biol. Chem. 53 (1989) 1009-1017.

[43] M. Kumari, A. Sharma, M.V. Jagannadham, Food Chem. 131 (2012) 1295-1303.

[44] I.A.M. Ahmed, I. Morishima, E.E. Babiker, N. Mori, Food Chem. 116 (2009) $395-400$

[45] H. Yonezawa, H. Kaizuka, T. Uchikoba, K. Arima, M. Kaneda, Biosci. Biotechnol. Biochem. 64 (2000) 2104-2108.
[46] C. Merheb-Dini, E. Gomes, M. Boscolo, R. da Silva, Food Chem. 120 (2010) 87-93.

[47] L. Ong, K. Soodam, S.E. Kentish, I.B. Powell, S.L. Gras, Int. Dairy J. 46 (2015) $53-62$.

[48] L. Ong, R.R. Dagastine, S.E. Kentish, S.L. Gras, Int. Dairy J. 33 (2013) 135-141.

[49] K.S. Ibrahim, J. Muniyandi, S. Karutha Pandian, J. Microbiol. Biotechnol. 21 (2011) 20-27.

[50] S. Emtenani, A. Asoodeh, S. Emtenani, Process Biochem. 48 (2013) 1679-1685.

[51] R. Kumari Narwal, B. Bhushan, A. Pal, A. Panwar, S. Malhotra, LWT Food Sci. Technol. 65 (2016) 652-660.

[52] M. Castillo, F.A. Payne, C.L. Hicks, M.B. Lopez, Int. Dairy J. 10 (2000) 551-562

[53] R.G. Beka, F. Krier, M. Botquin, V.D. Guiama, P. Donn, D.G. Libouga, C.M. Mbofung, K. Dimitrov, M.-C. Slomianny, D. Guillochon, D. Vercaigne-Marko, Int. Dairy J. 34 (2014) 25-31.

[54] S. Chazarra, L. Sidrach, D. López-Molina, J.N. Rodríguez-López, Int. Dairy J. 17 (2007) 1393-1400.

[55] A.F. Wolfschoon-Pombo, Int. Dairy J. 7 (1997) 249-254.

[56] M.A. Bruno, C.M. Lazza, M.E. Errasti, L.M.I. López, N.O. Caffini, M.F. Pardo, LWT Food Sci. Technol. 43 (2010) 695-701.

[57] E.V. Pontual, B.E.A. Carvalho, R.S. Bezerra, L.C.B.B. Coelho, T.H. Napoleão, P.M.G. Paiva, Food Chem. 135 (2012) 1848-1854

[58] Z. Zhang, Z. He, M. He, J. Mol. Catal. B: Enzym. 14 (2001) 85-94.

[59] D.L. Purich, Chapter 7 - factors influencing enzyme activity, in: D.L. Purich (Ed.), Enzyme Kinetics: Catalysis \& Control, Elsevier, Boston, 2010, pp. 379-484.

[60] T. Uchikoba, T. Niidome, I. Sata, M. Kaneda, Phytochemistry 33 (1993) 1005-1008.

[61] M. Kaneda, H. Yonezawa, T. Uchikoba, Biosci. Biotechnol. Biochem. 61 (1997) 2100-2102. 